\title{
Fortification, mining, and charcoal production: landscape history at the abandoned medieval settlement of Hohenwalde at the Faule Pfütze (Saxony, Eastern Ore Mountains)
}

\author{
Johann Friedrich Tolksdorf ${ }^{1}$, Matthias Schubert ${ }^{2}$, Frank Schröder $^{2}$, Libor Petr $^{3}$, Christoph Herbig ${ }^{4}$, Petr Kočár $^{5}$, \\ Mathias Bertuch $^{2}$, and Christiane Hemker ${ }^{2}$ \\ ${ }^{1}$ Praktische Denkmalpflege: Bodendenkmalpflege, Bayerisches Landesamt für Denkmalpflege, Thierhaupten, Germany \\ ${ }^{2}$ ArchaeoMontan Research Group, Landesamt für Archäologie Sachsen, Dresden, Germany \\ ${ }^{3}$ Department of Botany and Zoology, Masaryk University, Brno, Czech Republic \\ ${ }^{4}$ Institut für Archäologische Wissenschaften, Goethe-Universität Frankfurt am Main, Frankfurt, Germany \\ ${ }^{5}$ Institute of Archaeology, Czech Academy of Sciences, Prague, Czech Republic
}

Correspondence: Johann Friedrich Tolksdorf (johann.tolksdorf@ blfd.bayern.de)

Relevant dates: $\quad$ Received: 8 October 2018 - Revised: 3 December 2018 - Accepted: 10 December 2018 Published: 15 January 2019

How to cite:

Tolksdorf, J. F., Schubert, M., Schröder, F., Petr, L., Herbig, C., Kočár, P., Bertuch, M., and Hemker, C.: Fortification, mining, and charcoal production: landscape history at the abandoned medieval settlement of Hohenwalde at the Faule Pfütze (Saxony, Eastern Ore Mountains), E\&G Quaternary Sci. J., 67, 73-84, https://doi.org/10.5194/egqsj-67-73-2019, 2019.

Abstract: $\quad$ Geoarchaeological reconstructions of land-use changes may help to reveal driving cultural factors and incentives behind these processes and relate them to supra-regional economic and political developments. This is particularly true in the context of complete abandonment of a settlement. Here we present a case study from the site of Faule Pfütze, a small catchment in the Eastern Ore Mountains (Saxony). The historical record of this site is confined to the report of a settlement called Hohenwalde in $1404 \mathrm{CE}$ and two later references to the then-abandoned settlement in 1492 and $1524 \mathrm{CE}$ in this area. Combined geoarchaeological studies allowed for the reconstruction of several phases of land use. While a first phase of alluvial sedimentation occurred during the late 12th century, archaeological evidence for a permanent settlement is absent during this period. The onset of settlement activity is identified during the late 14th century and included a hitherto unknown massive stone building. Mining features are present nearby and are dated to the early 15 th century. The local palynological record shows evidence for reforestation during the mid 15 th century and thereby corroborates the time of abandonment indicated by written sources. These processes are discussed in the context of a local political conflict (Dohna Feud) leading to the redistribution of properties and the development of a mining economy during this time. Later land use from the mid 16th century onwards appears restricted to charcoal production, probably in the context of smelting works operating in nearby Schmiedeberg as indicated by rising lead concentrations in the alluvial record.

Kurzfassung: Geoarchäologische Rekonstruktionen der Landschaftsgeschichte können dazu dienen, die hinter diesen Prozessen liegenden kulturellen Triebkräfte und Motivationen offenzulegen und diese mit überregionalen ökonomischen und politischen Entwicklungen in Beziehung zu setzen. In besonders hohem 
Maße trifft dieses im Umfeld von vollständigen Wüstungsprozessen zu. Im Rahmen einer Fallstudie wird hier die Fundstelle an der "Faulen Pfütze", einer kleinen Siedlungskammer im Osterzgebirge (Sachsen), vorgestellt. Die historische Überlieferung zu dieser Fundstelle beschränkt sich auf die Nennung einer Siedlung "Hohenwalde" im Jahr 1404 sowie zwei spätere Nennungen aus dem Jahr 1492 und 1524, die sich bereits auf eine Wüstung in diesem Gebiet beziehen. Nur durch geoarchäologische Ansätze war es daher möglich, unterschiedliche Phasen der Landnutzungsgeschichte zu rekonstruieren. Während eine erste Phase der alluvialen Sedimentation bereits im späten 12. Jahrhundert festzustellen ist, fehlen archäologische Belege für eine dauerhafte Siedlung zu diesem Zeitpunkt noch völlig. Der Beginn der Siedlungsaktivitäten setzt im späten 14. Jahrhundert ein und umfasst dabei auch ein bislang unbekanntes massives Steingebäude. In unmittelbarer Nähe treten Bergbauspuren auf, die in das frühe 15. Jahrhundert datieren. Die palynologischen Analysen zeigen eine lokale Wiederbewaldungsdynamik ab der Mitte des 15. Jahrhunderts und bestätigen dabei den durch historische Quellen genannten Zeitpunkt der Siedlungsaufgabe. Diese Entwicklung wird vor dem Hintergrund eine regionalen Auseinandersetzung (Dohnaischen Fehde) diskutiert, die vor Ort nicht nur eine territoriale Neuverteilung sondern auch Bergbauaktivitäten zur Folge hatte. Spätere Landnutzung ab der Mitte des 16. Jahrhunderts scheint dann auf die Produktion von Holzkohle beschränkt gewesen zu sein, wahrscheinlich zur Versorgung der Hüttenwerke im nahen Schmiedeberg, was sich auch in steigenden Bleieinträgen in den alluvialen Sedimenten abzeichnet.

\section{Introduction}

A number of regional case studies have highlighted the influence of mining activities and related timber and charcoal production on central European mountain ranges (e.g. Stolz and Grunert, 2010; Hrubý et al., 2014; Knapp et al., 2015). In the Ore Mountains region silver and tin mining has been present at least since the mid 12th century based on historical sources (Wagenbreth, 1990), but archaeological and palaeoenvironmental investigations on this time period have been scarce compared to other regions. Due to the establishment of a border zone between East Germany and the Czechoslovakia from 1945 to 1990 and low construction activities, this area has not been in the focus of the heritage authorities on both sides of the border for decades. Moreover, the intensive mining activities in later centuries were expected to have destroyed most of the medieval structures. Palaeoenvironmental studies were restricted to pollen profiles from mires in the upper reaches of the Ore Mountains (Stebich, 1995; Schlöffel, 2010). Research activity in this area only resumed after the discovery of well-preserved mining features from the late 12th and 13th century in Dippoldiswalde in 2008 and led to the establishment of two German-Czech ArchaeoMontan research projects (Ziel-3 ArchaeoMontan from 2012 to 2015 and ArchaeoMontan 2018 from 2016 to 2018). In the course of these projects, local studies focussed on the medieval human impact around the town of Freiberg that have flourished as a silver mining centre since the mid 12th century (Tolksdorf et al., 2018) and the effects of mining activities together with timber and charcoal production since the late 12th century in the small mining district of Niederpöbel near Schmiedeberg in the Eastern Ore Mountains (Schröder, 2015; Tolksdorf et al., 2015). The results have indicated a strong impact in the form of deforestation, a sharp decline of tree species like Abies alba and changes in forest composition during ongoing land use. This case study addresses the land-use history of a comparatively short-lived village in the Ore Mountains in the context of local mining activities and the regional political history.

\section{Site topography and sampling}

The site of Faule Pfütze is located in the Eastern Ore Mountains (Osterzgebirge in German) about $30 \mathrm{~km}$ south of Dresden (Fig. 1a) in a mountain ridge east of Schmiedeberg (Fig. 1b) and was investigated by the ArchaeoMontan 2018 team in 2016 and 2017. Local geology is dominated by quartz porphyries and porphyroid granites (GK 25, 1915; Reinisch, 1915). In the study area the small valley of the Brießnitzbach river opens to the east, and the modern site name "Faule Pfütze" (meaning "brackish pool" in German) relates to the wetlands around the spring area of this river. Microtopographical assessment of lidar data reveals several sunken roads that converge in the area of a modern dam used for the road, creating a small pond. Some mining features (shafts, mining heaps) can be recognized by their specific topography to the southeast. Additional charcoal kilns in the form of round platforms are visible on the surrounding slopes (Fig. 2a).

Immediately downstream of the modern dam, the upper $110 \mathrm{~cm}$ of alluvial sediments was accessible in an outcrop cut by the river and sampled as profile 1 for macro-botanical, palynological, geochemical, and ${ }^{14} \mathrm{C}$ analyses. A dense layer of rubble just a few metres upstream of profile 1 was noted as an archaeological feature and labelled profile 3 . To substantiate the age of the mining features, profile 2 was situated beside 


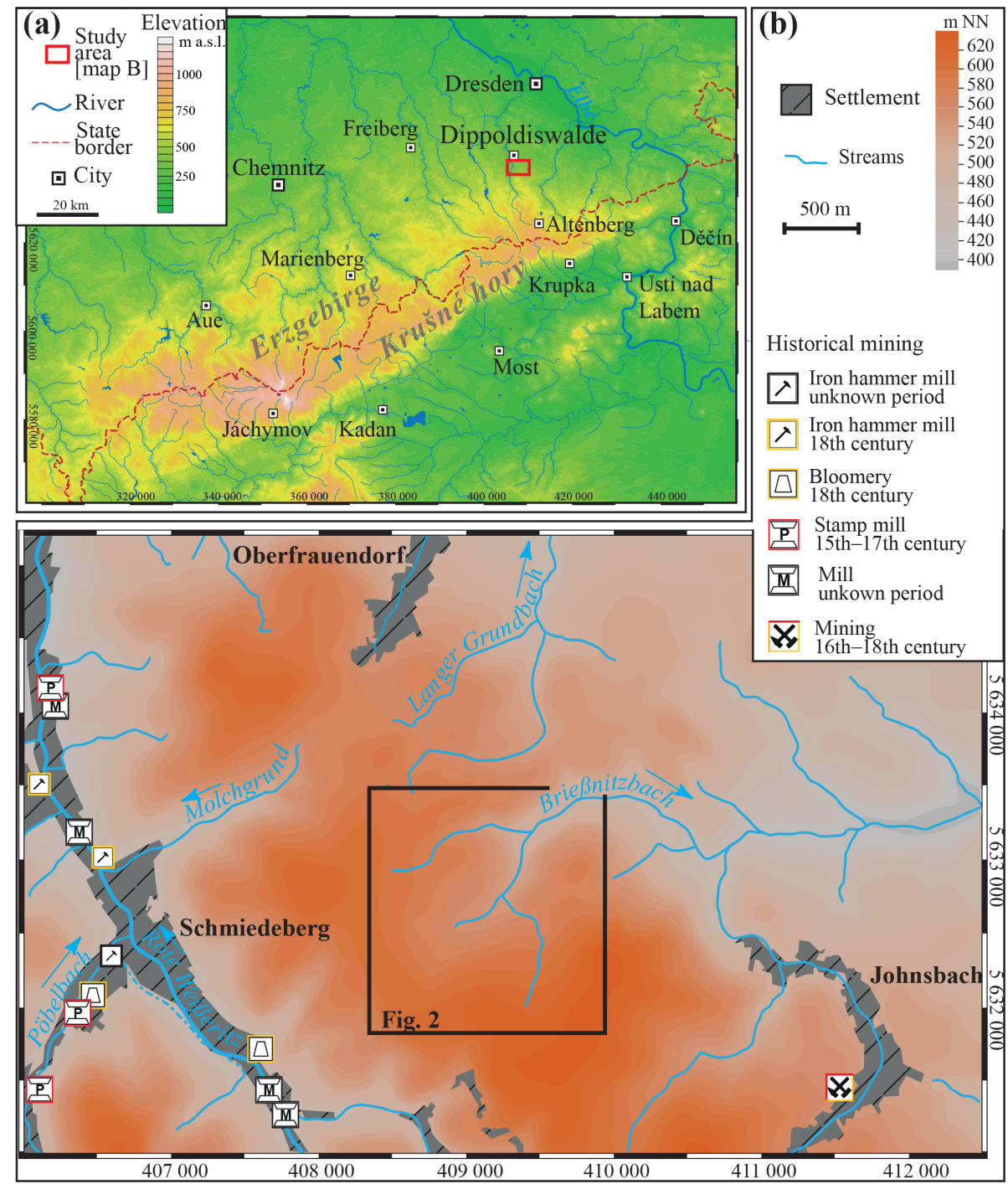

Figure 1. (a) Location of the site of Faule Pfütze in the Ore Mountains (data: SRTM), (b) regional topography (data: GeoSN). Historical mining features are mapped according to historical maps (Ur-Oder and Oeder-Zimmermann from early 17th century) and written sources (Müller, 1964) using the symbols and time periods from Göhler and Wehmeyer (2013).

a mining heap in order to sample the palaeo-surface covered by mining waste for botanical (BOT-36) and ${ }^{14} \mathrm{C}$ analyses (MAMS-30882).

The valley bottom above profile 1 yielded numerous ceramic fragments on the surface. Here, profile 4 was recorded to document the relation of settlement layers to alluvial and colluvial sediments, while profile 5 was situated at the transition from the southern hillslope to the alluvial plain. A prominent feature visible in the digital elevation model (DEM) derived from lidar scan is a stone heap with a square layout rising more than $1 \mathrm{~m}$ above the valley floor. Profile 6 was used to record a profile in this feature and profile 7 was used for archaeological investigation of the valley floor nearby. Sedimentation history on the valley floor was recorded using a transect consisting of six cores and profiles 1 and 3 (Fig. 2b) from the southeast to the northwest.

\section{Methods and material}

Botanical macro-remains were retrieved from sediment samples by wet sieving with mesh widths of $2,1,0.5$, and $0.25 \mathrm{~mm}$ and determined according to standard literature (Cappers et al., 2012) and a reference collection of wild and domestic plants. Their attribution to ecological groups is based on the classification by Oberdorfer (2001). Sample preparation for pollen analysis followed standard acetolysis procedure, and a minimum number of 500 palynomorphs were identified according to literature (Beug, 2004) in every sample. A portable X-ray fluorescence (XRF) unit (Olympus 

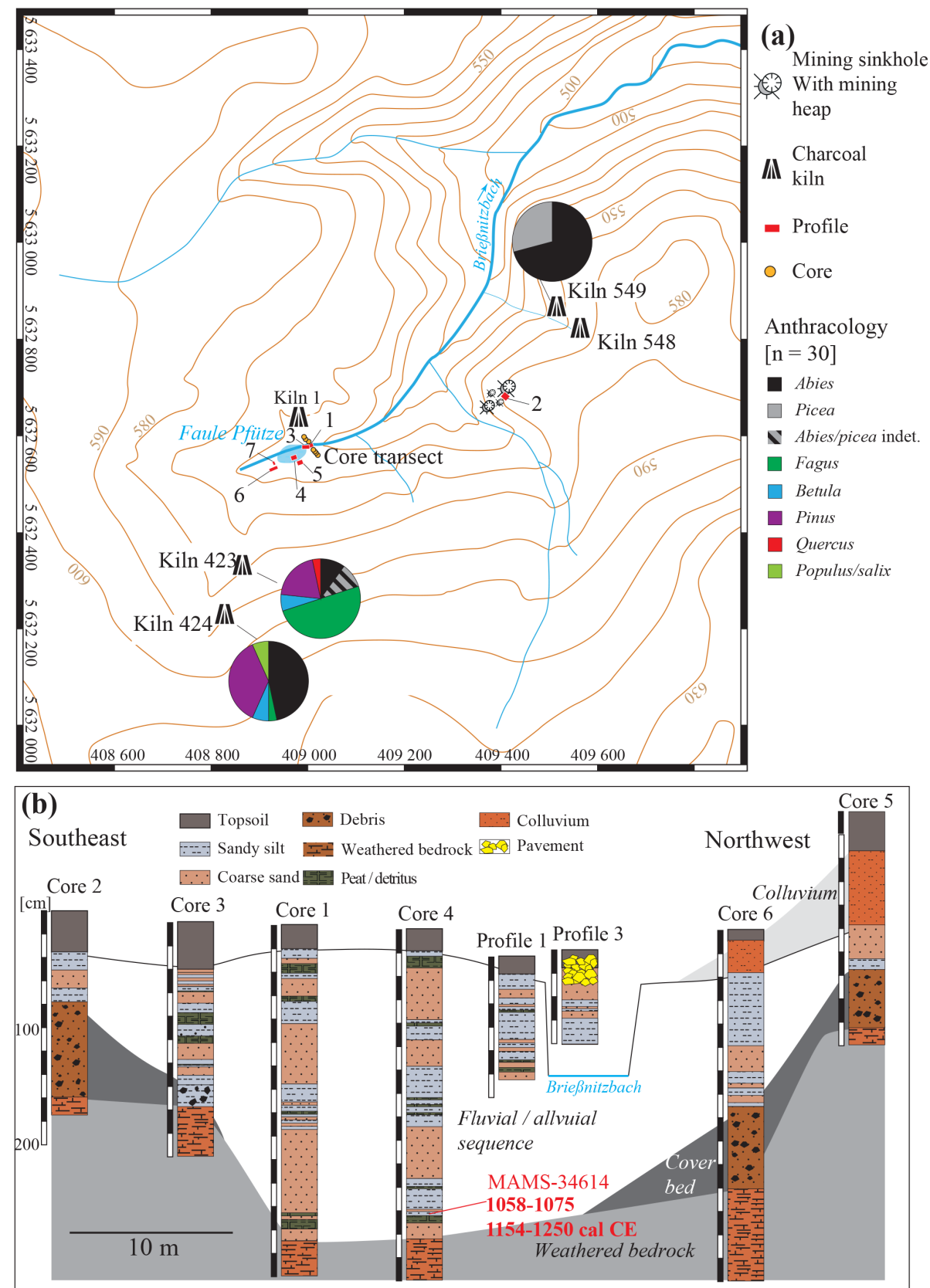

Figure 2. (a) Site topography, sampled records, and results of anthracological analysis of charcoal kilns from this area; (b) stratigraphic logs of the core transect through the valley floor.

Innov-X DELTA 50) was used to measure geochemical properties on dried samples from the grain-size fraction $<0.8 \mathrm{~mm}$ (CGS Prague Laboratories). Changing concentrations of the elements $\mathrm{Pb}, \mathrm{As}$, and $\mathrm{Zn}$ were used as potential environmental proxies for metallurgical activities (Hürkamp et al., 2009; Schmidt-Wygaasch et al., 2010). The ${ }^{14} \mathrm{C}$ analyses were performed by the Curt-Engelhorn-Zentrum Archäometrie (CEZ) in Mannheim, and calibrated using IntCal13 (Table 1) and the Bayesian model implemented in OxCal. Samples of 30 charred particles were extracted from three charcoal kilns for an anthracological assessment. Determination of the taxa is based on wood-anatomical features on fresh cuts with different orientations (Schweingruber, 1990). Due to their anatomical similarity Populus and Salix were grouped together. The dating of ceramics was based on typological and technological parallels with well-dated archaeological assemblages in the region (Mechelk, 1981). A series of overlapping photos was used to process 3-D models for larger archaeological features by structure from motion (SfM). Consequently, the 
Table 1. Results of ${ }^{14} \mathrm{C}$ analyses.

\begin{tabular}{|c|c|c|c|c|c|c|}
\hline Lab no. & Profile & $\begin{array}{l}\text { Material and } \\
\text { context }\end{array}$ & ${ }^{14} \mathrm{C}$ & 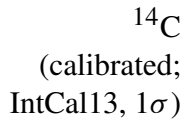 & 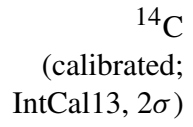 & $\begin{array}{r}\delta^{13} \mathrm{C} \\
(\% o)\end{array}$ \\
\hline & & & (BP) & (cal CE) & (cal CE) & \\
\hline MAMS- & profile 1 & charcoal from & $282 \pm 16$ & $1528-1544$ & $1522-1573$ & -23.6 \\
\hline 30884 & & $\begin{array}{l}\text { alluvial layer } 18-25 \mathrm{~cm} \\
\text { below surface }\end{array}$ & & $1634-1650$ & $1630-1657$ & \\
\hline MAMS- & profile 1 & charcoal & $333 \pm 17$ & $1499-1504$ & $1487-1638$ & -23.9 \\
\hline 30883 & from alluvial layer & $\begin{array}{l}49-55 \mathrm{~cm} \\
\text { below surface }\end{array}$ & & $\begin{array}{l}1512-1527 \\
1555-1601 \\
1617-1633\end{array}$ & & \\
\hline $\begin{array}{l}\text { MAMS- } \\
32962\end{array}$ & profile 1 & $\begin{array}{l}\text { charcoal from } \\
\text { alluvial layer } 75 \mathrm{~cm} \\
\text { below surface }\end{array}$ & $401 \pm 19$ & $1447-1479$ & $\begin{array}{l}1441-1498 \\
1601-1616\end{array}$ & -17.6 \\
\hline $\begin{array}{l}\text { MAMS- } \\
30882\end{array}$ & profile 2 & $\begin{array}{l}\text { charcoal below } \\
\text { mining heap }\end{array}$ & $510 \pm 17$ & $1414-1430$ & $1408-1437$ & -23.1 \\
\hline $\begin{array}{l}\text { MAMS- } \\
33862\end{array}$ & profile 4 & $\begin{array}{l}\text { charcoal concentration } \\
\text { below alluvial layers, } \\
55 \mathrm{~cm} \text { below surface }\end{array}$ & $\begin{array}{r}953 \pm 22 \\
1086-1124\end{array}$ & $\begin{array}{l}1029-1049 \\
1065-1155 \\
1137-1150\end{array}$ & $\begin{array}{l}1023-1059 \\
1065-1155\end{array}$ & -25.7 \\
\hline $\begin{array}{l}\text { MAMS- } \\
33861\end{array}$ & profile 6 & $\begin{array}{l}\text { charcoal, under } \\
\text { embankment } 80 \mathrm{~cm} \\
\text { below surface }\end{array}$ & $593 \pm 24$ & $\begin{array}{l}1315-1356 \\
1389-1400\end{array}$ & $\begin{array}{l}1300-1369 \\
1381-1410\end{array}$ & -29.2 \\
\hline $\begin{array}{l}\text { MAMS- } \\
34614\end{array}$ & core 4 & $\begin{array}{l}\text { charcoal from } \\
\text { base of alluvial } \\
\text { sediments }\end{array}$ & $857 \pm 23$ & $1167-1214$ & $\begin{array}{l}1058-1075 \\
1154-1250\end{array}$ & -29.0 \\
\hline $\begin{array}{l}\text { MAMS- } \\
32530\end{array}$ & $\begin{array}{l}\text { charcoal kiln } \\
423\end{array}$ & charcoal kiln & $311 \pm 21$ & $\begin{array}{l}1522-1575 \\
1586-1590 \\
1625-1642\end{array}$ & $\begin{array}{l}1495-1602 \\
1616-1646\end{array}$ & -23.9 \\
\hline
\end{tabular}

structures were mapped in a local coordinate system with the surrounding surface as the vertical reference level.

\section{Results}

The auger transect through the valley floor around profile 1 shows a complex sequence of coarse fluvial sands and alluvial silt that partly cover the periglacial cover beds dominated by gravels (Fig. 2b). Fine layers of organic detritus were preserved within some of the alluvial silt units. Colluvial layers appear at the northern slope covering the alluvial layers. $\mathrm{A}{ }^{14} \mathrm{C}$ sample from the lowermost alluvial layer in core 4 yielded an age of $1058-1075$ or $1154-1250$ cal CE (MAMS-34614).

Profile 1 was recorded at a location where the river at the outlet of the modern dam incised into the valley floor. The sequence exposed along the bank consists of alluvial layers with organic detritus and coarse fluvial sands (Fig. 3). Based on three ${ }^{14} \mathrm{C}$ analyses (MAMS-30883, MAMS-30884, MAMS-32962), these layers have been deposited from the early 15 th century to the early 17 th century. The content of botanical macro-remains differs between the alluvial layers but is consistently dominated by wetland taxa. The ratio of arboreal to non-arboreal pollen within the three lowermost pollen samples shows recovering forest vegetation up to a depth of $61 \mathrm{~cm}$. The sample at $55 \mathrm{~cm}$ is characterized by a high percentage of micro-charcoal and declining arboreal pollen. Geochemical analyses show a relatively stable concentration of zinc and arsenic but a distinct rise in lead concentrations at a depth of about $50 \mathrm{~cm}$. Based on the chronological model, both the drop of arboreal pollen and the rise of lead content are ascribed to the 15 th to 16 th century.

The detailed analysis of the pollen spectra (Fig. 4) reveals a very high percentage of Corylus avellana pollen in the lowermost sample at $90 \mathrm{~cm}$. The subsequent samples at $75 \mathrm{~cm}$ show a sharp decline of Corylus but increasing percentages of Abies, Pinus, and Picea pollen. At a depth of $61 \mathrm{~cm}$ the share of Abies pollen declined again while Pinus and Picea are still expanding. Although pollen from Secale cereale and Centaurea cyanus as well as ruderal taxa like Plantago lanceolata or Rumex acetosella are present in these lower three samples, their low number indicates that permanent settlement and arable land could have existed only at some distance. Additional information about the local vegetation is provided by the macro-botanical spectra at 75 , 67 , and $61 \mathrm{~cm}$ depth. These present a dominance of wetland 
Table 2. Macro-botanical and anthracological results.

\begin{tabular}{|c|c|c|c|c|c|c|c|c|c|c|c|c|c|c|c|c|}
\hline \multicolumn{4}{|c|}{$\begin{array}{l}\text { Sample (BOT: macro-remains; HK: anthracology) } \\
\text { cf. Figs. } 2 \text { and } 3 \text { for sample location }\end{array}$} & BOT-53 & BOT-54 & BOT-62 & BOT-63 & BOT-64 & BOT-65 & BOT-36 & BOT-79 & BOT-80 & BOT- 85 & HK-14 & HK-15 & HK-16 \\
\hline \multicolumn{4}{|c|}{$\begin{array}{l}\text { Sample size (litres or } \\
\text { pieces (pcs.)) }\end{array}$} & 0.11 & 0.11 & 0.11 & 0.11 & 0.11 & 0.11 & 0.21 & 0.11 & 0.11 & 0.11 & $\begin{array}{c}30 \\
\text { pcs. }\end{array}$ & $\begin{array}{r}30 \\
\text { pcs. }\end{array}$ & $\begin{array}{r}30 \\
\text { pcs. }\end{array}$ \\
\hline \multicolumn{4}{|c|}{ Depth (cm) } & 75 & 47 & 51 & 56 & 61 & 67 & 120 & $14-29$ & $29-49$ & 200 & 10 & 10 & 10 \\
\hline \multicolumn{4}{|c|}{ Profile } & 1 & 1 & 1 & 1 & 1 & 1 & 2 & 4 & 4 & 4 & kiln & kiln & kiln \\
\hline & Taxonomy & Anatomy & $\begin{array}{l}\text { Preser- } \\
\text { vation }\end{array}$ & & & & & & & & & & & & & \\
\hline \multirow{15}{*}{ 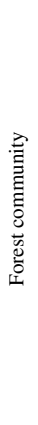 } & Abies alba & ND & $\mathrm{u}$ & 5 & & 9 & & 4 & 9 & & & & 2 & & & \\
\hline & & $\begin{array}{l}\text { ND } \\
\text { W }\end{array}$ & $\begin{array}{l}\mathrm{ch} \\
\mathrm{ch}\end{array}$ & & & 21 & & & & 500 & & 36 & 180 & 3 & 14 & 17 \\
\hline & Picea abies & ND & $\mathrm{u}$ & 9 & & & & 11 & 11 & & 23 & 7 & & 3 & 14 & \\
\hline & & ND & $\mathrm{ch}$ & & & 4 & & & & & & & & & & \\
\hline & & $\mathrm{W}$ & $\mathrm{ch}$ & & & & & & & & & & & & & 7 \\
\hline & Abies and Picea indet. & $\mathrm{W}$ & $\mathrm{ch}$ & & & & & & & & & & & 3 & & \\
\hline & Pinus & ND & $\mathrm{ch}$ & & & & & & & 5 & & & & & & \\
\hline & & $\mathrm{W}$ & ch & & & & & & & & & & & 6 & 11 & \\
\hline & Populus sp. & FS & $\mathrm{u}$ & & & & & 1 & 1 & & & & & & & \\
\hline & & $\mathrm{W}$ & ch & & & & & & & & & & & & 1 & \\
\hline & Populus and Salix indet. & W & ch & & & & & & & & & & & & 1 & \\
\hline & Carpinus betulus & FS & $\mathrm{ch}$ & & & & & & & 1 & & & & & & \\
\hline & Fagus sylvatica & W & ch & & & & & & & & & & & 15 & 1 & \\
\hline & Quercus robur & W & ch & & & & & & & & & & & 1 & & \\
\hline & Oxalis acetosella & FS & $\mathrm{u}$ & & 1 & 1 & & & & & & & & & & \\
\hline \multirow{7}{*}{ 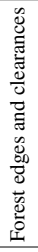 } & Arctium sp. & FS & $\mathrm{u}$ & & & & 1 & & & & & & & & & \\
\hline & Betula pendula and & FS & $\mathrm{u}$ & 11 & & 1 & & & 6 & & & & & & & \\
\hline & pubescens & W & $\mathrm{c}$ & & & & & & & & & & & 2 & 2 & \\
\hline & Carex ovalis & FS & $\mathrm{u}$ & & & & 1 & 1 & 1 & & & & & & & \\
\hline & Hypericum hirsutum & FS & $\mathrm{u}$ & & & & & & 1 & & & & & & & \\
\hline & Sambucus nigra & FS & ch & & & & & & & & & & 2 & & & \\
\hline & Rubus fructicosus agg. & FS & $\mathrm{u}$ & & & & 1 & & & & & & & & & \\
\hline \multirow{5}{*}{ 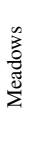 } & Cerastium fontanum & $\mathrm{R}$ & $\mathrm{u}$ & 4 & 1 & 5 & & 1 & 3 & & & & & & & \\
\hline & $\begin{array}{l}\text { Luzula campestris } \\
\text { and } L . \text { multiflora }\end{array}$ & FS & $\mathrm{u}$ & & 2 & & 1 & & & & & & & & & \\
\hline & Origanum vulgare & FS & $\mathrm{u}$ & & 1 & & & & & & & & & & & \\
\hline & Prunella vulgaris & FS & $\mathrm{u}$ & & & & & & 1 & & & & & & & \\
\hline & Rumex acetosella agg. & FS & $\mathrm{u}$ & & & 1 & & 1 & & & & & & & & \\
\hline \multirow{8}{*}{ 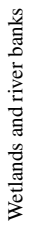 } & Carex sp. & FS & $\mathrm{u}$ & 13 & 1000 & 300 & 359 & 195 & 480 & & & & & & & \\
\hline & Glyceria fluitans & FS & $\mathrm{u}$ & 114 & & 32 & 50 & 4 & 115 & & & & & & & \\
\hline & Montia fontana s.l. & FS & $\mathrm{u}$ & 41 & & 8 & 4 & & & & & & & & & \\
\hline & Potamogeton sp. & FS & $\mathrm{u}$ & & 2 & & & & & & & & & & & \\
\hline & Ranunculus flammula & FS & $\mathrm{u}$ & 1 & 4 & 8 & 17 & 8 & 8 & & & & & & & \\
\hline & Scirpus sylvaticus & FS & $\mathrm{u}$ & 1 & & 10 & 33 & 10 & 10 & & & & & & & \\
\hline & Sparganium emersum & FS & $\mathrm{u}$ & & 1 & & & & & & & & & & & \\
\hline & Sphagnum & FS & $\mathrm{u}$ & + & & & & & & & & & & & & \\
\hline \multirow{15}{*}{ 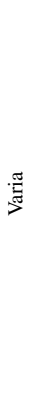 } & Chenopodium album type & FS & $\mathrm{u}$ & & & & 1 & & & & & & & & & \\
\hline & Carduus and Cirsium & FS & $\mathrm{u}$ & & & & & 1 & & & & & & & & \\
\hline & Juncus sp. & FS & $\mathrm{u}$ & 5 & 7 & 9 & 7 & 1 & 2 & & 36 & 31 & 60 & & & \\
\hline & Lamiaceae & FS & $\mathrm{u}$ & & 1 & & & & & & & & & & & \\
\hline & Myosotis sp. & FS & $\mathrm{u}$ & 1 & & & & & & & & & & & & \\
\hline & Pinaceae & FS & $\mathrm{u}$ & & & & & & 1 & & & & & & & \\
\hline & Poa sp. & FS & $\mathrm{u}$ & 5 & 1 & & & & & & & & & & & \\
\hline & Polygonum aviculare agg. & FS & $\mathrm{u}$ & & & & 2 & & & & & & & & & \\
\hline & Sagina procumbens & FS & $\mathrm{u}$ & & & & 1 & & & & & & & & & \\
\hline & Viola sp. & FS & $\mathrm{u}$ & & 18 & 1 & 5 & 1 & & & & & & & & \\
\hline & $\begin{array}{l}\text { Rumex crispus } \\
\text { or } R \text {. obtusifolius }\end{array}$ & FS & $\mathrm{ch}$ & & & & & & 1 & & & & & & & \\
\hline & Indeterminate & FS & $\mathrm{u}$ & & 1 & & & & & & & & & & & \\
\hline & Indeterminate & W & $\mathrm{u}$ & + & + & + & & + & & & & & & & & \\
\hline & Indeterminate & $\mathrm{W}$ & ch & + & + & + & + & + & + & & & & & & & \\
\hline & Indeterminate & $\mathrm{R}$ & $\mathrm{u}$ & 4 & & & & & 4 & & & & & & & 6 \\
\hline
\end{tabular}

taxa like Glyceria fluitans or Montia fontana with increasing numbers of Carex species. Remains of taxa which tend to occur on more open areas such as meadows or clearances like Cerastium fontanum, Betula, or Carex ovalis are seldom found and even show a decline that is in good accordance with the expansion of forest vegetation visible in the pollen.
However, direct evidence of forest species like fir or pine is rare in these samples.

The trend towards a recovery of the forest vegetation seems to be interrupted at a depth of $55 \mathrm{~cm}$ with declining percentages of Pinus, Picea, and Abies pollen accompanied by rising values of Corylus and species related to open ar- 


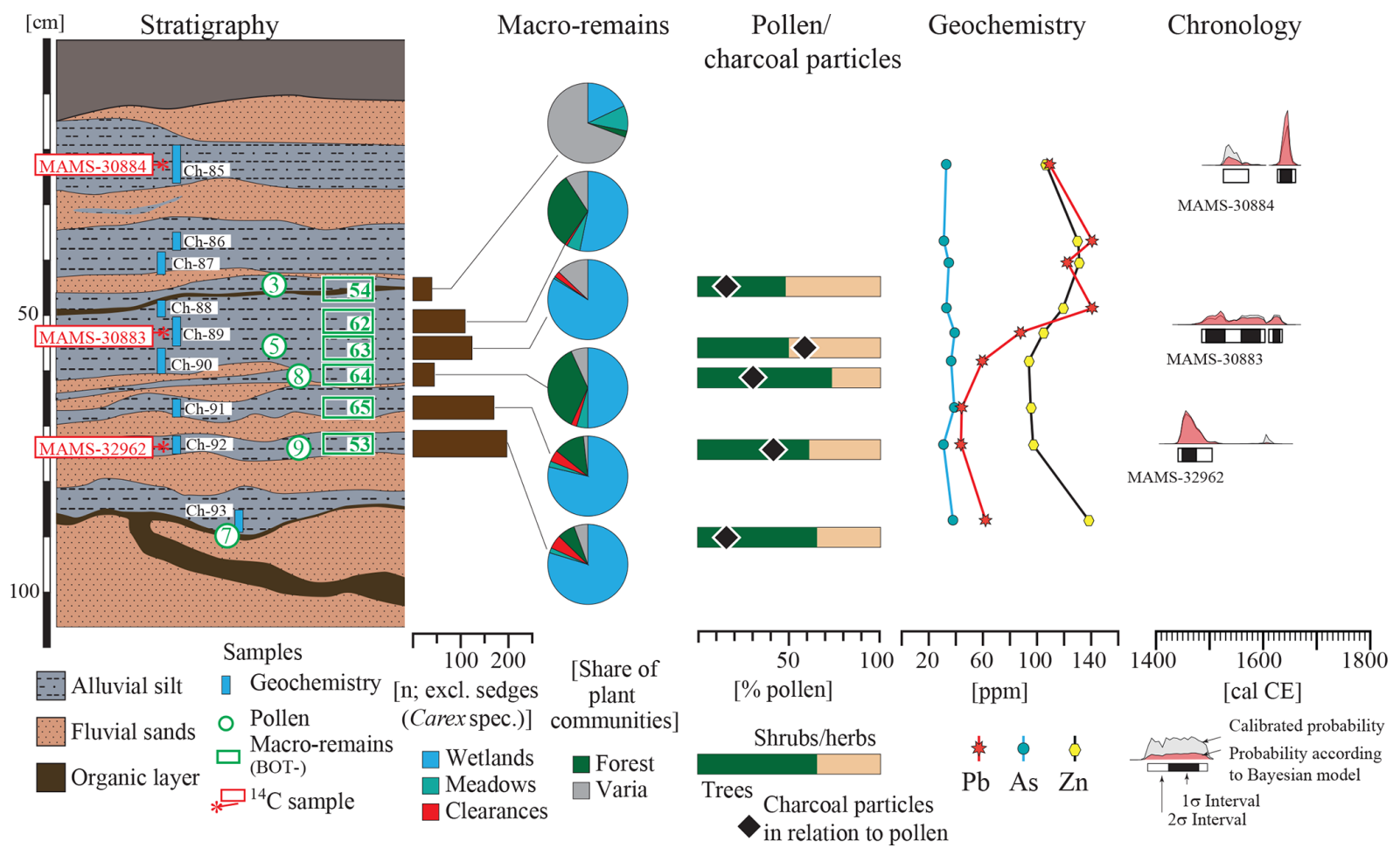

Figure 3. Stratigraphy, chronology, and key results of palynological, macro-botanical, and geochemical analyses in profile 1.

eas, especially Poaceae and Cyperaceae together with Rumex acetosella and Artemisia. The macro-botanical samples from this layer show a complete absence of taxa related to forest vegetation. While evidence for forest species is visible again in the macro-botanical spectrum at a $51 \mathrm{~cm}$ depth, the macro remains at a $47 \mathrm{~cm}$ depth and a pollen spectrum at a $45 \mathrm{~cm}$ depth are consistent with a reduction of forest taxa. Particularly, the very high number of Rumex acetosella pollen in the uppermost sample might indicate the permanent establishment of open areas, perhaps meadows.

Mining activity in this area is proven by profile 2 (Fig. 5a), which revealed a layer of charred material below a mining heap. Abies alba needles dominated the charred material by far (BOT-36) and prove that it results from the burning of local vegetation rather than technological processes like firesetting or smelting. The material yielded an age of 1408 1437 cal CE (MAMS-30882) providing a minimum age for the mining activities.

The square stone heap was investigated at profile 6 (Fig. 5b) and revealed a stone wall construction covered by an embankment. Residues of the former topsoil below the embankment contained ceramic fragments, an iron nail, and charred material, yielding a ${ }^{14} \mathrm{C}$ age of $1300-1369$ or $1381-1410$ cal CE. It is in very good accordance with the typochronological dating of the ceramic material discovered below the layers of relocated rubble in profile 7 (Fig. 5d). This was assigned to the end of the 14th century and later based on the presence of high- and undercut-shaped collar rims (hohe und unterschnittene Kragenränder) and reddish high-fired earthenware (rotscherbige hochgebrannte Irdenware; Mechelk, 1981).

While profile 5 at the transition from the slope to the alluvial plain only yielded relocated coarse material, nearby profile 4 showed intercalating layers of alluvial sedimentation and colluvial material (Fig. 5c). At a depth of $50 \mathrm{~cm} \mathrm{a}$ dense layer of charred material was covered by alluvial sediments. This material (BOT-85) was dominated by charred Abies alba needles but also contained remains of local Juncus species. Remains of Sambucus nigra could indicate the existence of clearances. A ${ }^{14} \mathrm{C}$ analysis provided an age of 1023-1155 cal CE for this layer. It was covered by colluvial sediments that contained charred remains of Abies and Juncus but also Picea needles (BOT-80). The subsequent alluvial layer from a 30 to $12 \mathrm{~cm}$ depth contained charred and uncharred botanical remains (Picea together with Juncus and Carex species) together with ceramic fragments dating to the 14 th century by means of typochronology. Remains of fir were absent in this younger layer.

Some small plateaus visible in the DEM were identified as charcoal kilns (Fig. 2a). While kiln 549 only contained remains of Abies and Picea, the fuel spectra of the kilns 423 and 424 were very broad and contained Fagus, Abies, Picea, Betula, Populus/Salix (indiff), and Quercus of differing proportions. A ${ }^{14} \mathrm{C}$ analysis of kiln 423 provided an age of $1495-$ $1646 \mathrm{cal} \mathrm{CE}$. 


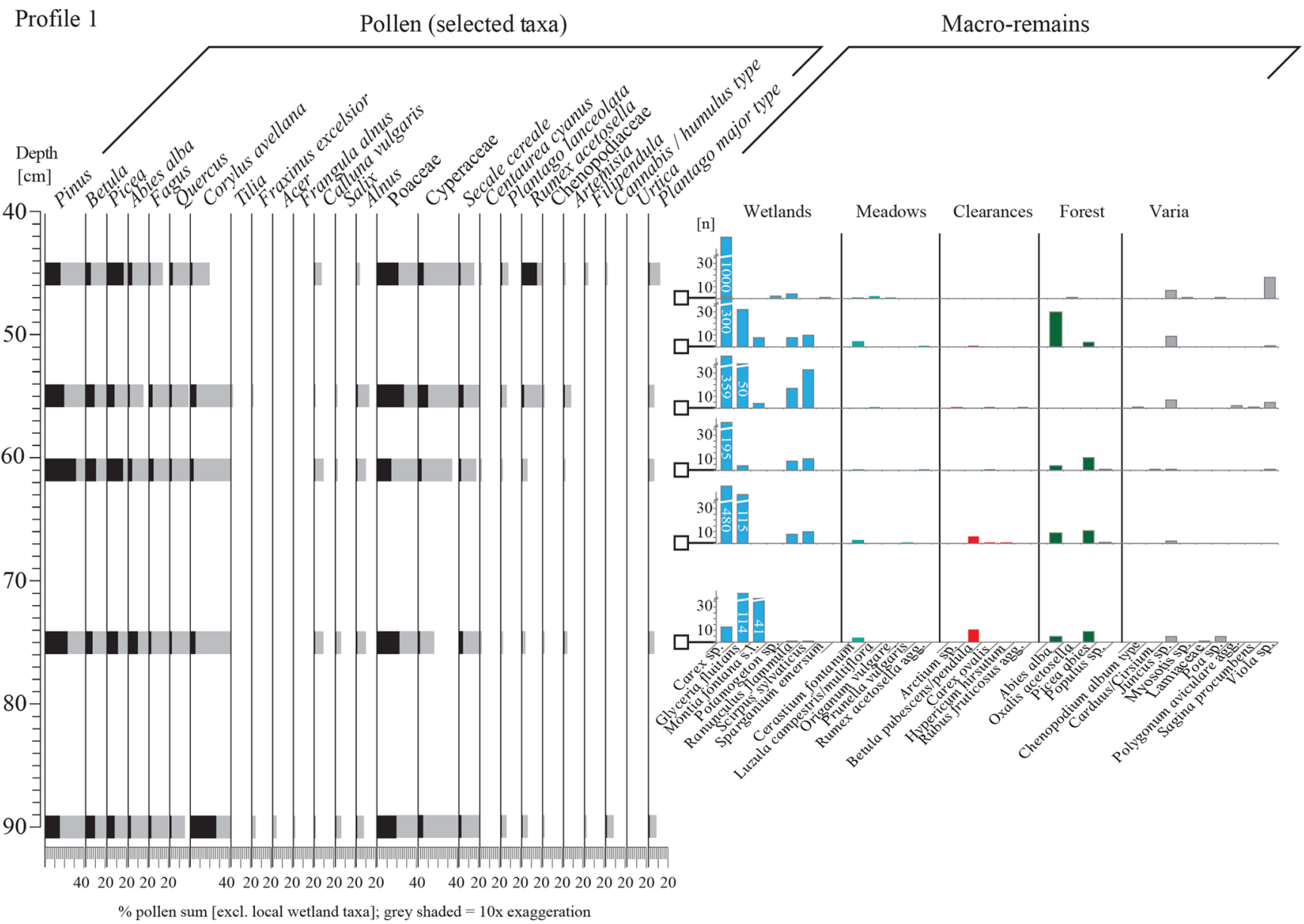

Figure 4. Palynological and macro-botanical spectra from profile 1 (cf. Fig. 3).

\section{Discussion}

The onset of alluvial sedimentation dates back to the 12th century based on ${ }^{14} \mathrm{C}$ ages from charcoal taken from profile 4 and core 4 . Although catastrophic events like wildfires could theoretically trigger local soil erosion (Shakesby and Doerr, 2006), human impact is a more likely cause. From the regional perspective, the 12th century is known as a time period with intensive rural colonization and mining in the Ore Mountains (Billig and Geupel, 1992; Kenzler, 2013). The earliest timber from the nearby medieval mines of Dippoldiswalde (about $7 \mathrm{~km} \mathrm{NNW)} \mathrm{could} \mathrm{indicate} \mathrm{the} \mathrm{start} \mathrm{of}$ mining in the region at the turn of the 12th to the 13th century (Hoffmann, 2011; Westphal et al., 2014). However, at the site of Faule Pfütze, the artefact assemblage and archaeological features suggest permanent human activity to have occurred from the 14th century onwards. It may be possible that this settlement phase was preceded by phases of ephemeral land use with low archaeological visibility, e.g. logging or pasture. Botanical spectra from this time preceding the settlement (BOT-80, BOT-85) contain high shares of Abies alba (fir) needles compared to other taxa like Picea abies (spruce) or Pinus sylvestris (pine) and may indicate the dominance of fir in the forest composition. However, such evidence neither support nor preclude earlier human activities in the area.

Human settlement on this site during the 14th century is undisputed and included the construction of the massive building recorded in profiles 6 and 7. Based on the construction technique, the ground plan, and the archaeological material, this feature represents the remains of what is possibly some sort of fortification (cf. Schwabenicky, 1996), but definitely a solid stone-built structure. The onset of mining may have occurred later as indicated by the ${ }^{14} \mathrm{C}$ age from profile 2 (Fig. 6, phase 1). Identifying the political and economic context of the strong building and the mining activities is problematic as major territorial changes took place in the region after the Dohna Feud (1385-1402 CE) (Ermisch, 1902; Hoffmann, 2011). Eventually, the first historical record concerning the village of Hohenwalde in $1404 \mathrm{CE}$ appears in the aftermath of these events when land ownership had changed (Müller, 1964). It is possible that mining activities have been fostered in this region by the new owner. Another aspect worth discussing is the function of the massive building. It may have either protected the settlement and 

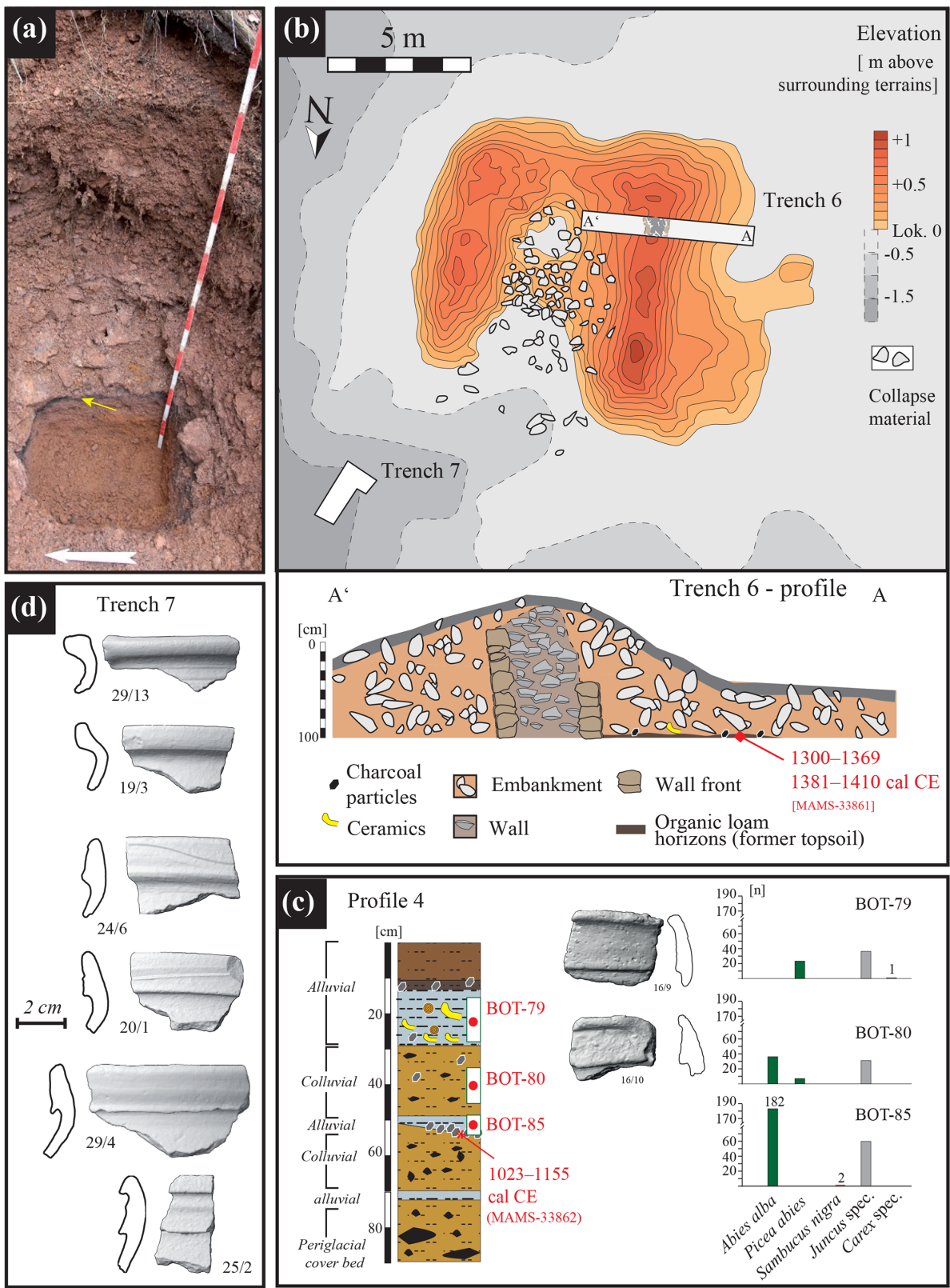

Figure 5. (a) Layer of burnt material (yellow arrow) below mining heap; (b) topography of the fortified building with profile recorded in profile 6; (c) profile 4 with macro-botanical analyses and chronological results; (d) selected artefacts from the site dating to the 14th century.

the road or been related to the protection of older mining facilities as discussed for other regions of the Ore Mountains (Schwabenicky, 1996; Kenzler, 2009). However, no historical record from this area ever refers to a fortification or mining activities, highlighting the incompleteness of this type of source. Botanical spectra from the settlement period derive from the burnt material below the mining heap (BOT-36) with abundant charred Abies alba needles and the upper part of profile 4 (BOT-79), where the dominance of Picea abies probably mirrors the local vegetation on the wet valley floor.
No cultivated plants or weeds have been detected in any sample.

The abandonment of the settlement can be narrowed down by combining the historical sources mentioning an abandoned village in $1492 \mathrm{CE}$ and the ${ }^{14} \mathrm{C}$ time depth model in profile 1 . Here the beginning of the ecological succession is dated to the mid 15th century (Fig. 6, phase 2), marked by a high share of pioneer taxa like Corylus avellana (hazel) and the absence of settlement indicators. During later decades, Abies, followed by Picea and Pinus, established in the area. Layers dated to the mid 16th century in profile 1 reveal a de- 


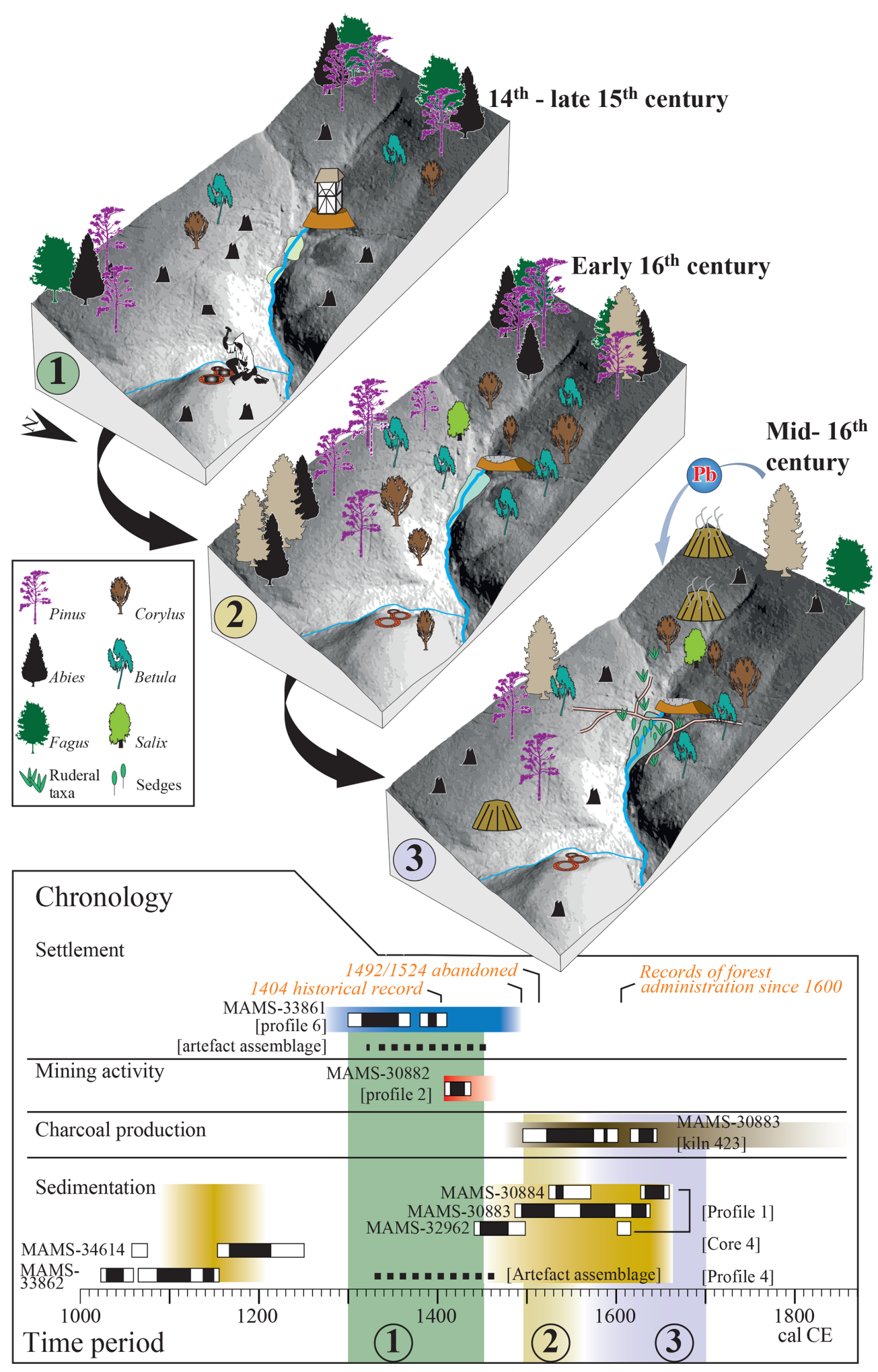

Figure 6. Reconstruction of land-use history at the site. Phase 1: settlement and mining activities during the 14th and early 15th centuries; phase 2: recovering forest vegetation after the settlement was abandoned in the mid 15th century; phase 3: metallurgical plants in Schmiedeberg since the mid 16th century prompt charcoal production and cause increased lead pollution. 
clining share of arboreal pollen and rising contents of charcoal particles (Fig. 6, phase 3). This suggests resuming land use in this area, probably for the purpose of charcoal production. It is supported by a ${ }^{14} \mathrm{C}$ date of $1495-1602$ or $1616-$ 1646 cal CE (MAMS-32530) from charcoal kiln 423 and historical sources from the late 16th century (Reinhold, 1942). Rising lead concentrations in the upper part of profile 1 probably result from intensified metallurgical activities in nearby Schmiedeberg $(2 \mathrm{~km} \mathrm{E})$ where smelting works were established during this period (Müller, 1964). While the pollen spectra capture a rising percentage of spruce in this area, the spectra from the charcoal kilns are more diverse, with pioneer taxa like Betula on the one hand and forest taxa like Fagus sylvatica and Abies alba on the other hand, and may simply reflect the natural local vegetation variety. The use of this area for logging and charcoal production continued until modern times; today the area is mainly covered by Picea plantations.

\section{Conclusions}

Our results indicate local settlement activities at least since 14th century CE and the existence of a strong building in this settlement may point towards the need to secure the area and its resources during this time period. It is likely that this area was affected by political reorganization following a feud in $1402 \mathrm{CE}$, and mining activities dating to the early 15th century may relate to a changed political and organizational background of the settlement that must have failed since the mid 15th century as indicated by reforestation and historical sources. Land use shifted to charcoal production to supply the striving metallurgical activities in the nearby Schmiedeberg area since the 16th century CE.

Data availability. All raw data and artefacts are stored at the Landesamt für Archäologie Sachsen (dataset code: OFD-01) and can obtained upon reasonable request.

Author contributions. Fieldwork was performed by JFT, MS, FS, and MB under the project supervision of $\mathrm{CH}$. Pollen analysis was done by LP, anthracological analyses by PK, and analysis of botanical remains by $\mathrm{CH}$. JFT prepared the manuscript and figures.

Competing interests. The authors declare that they have no conflict of interest.

Special issue statement. This article is part of the special issues "Geoarchaeology and past human-environment interactions". It is not associated with a conference.
Acknowledgements. This research was part of the project "ArchaeoMontan - Mittelalterlicher Bergbau in Sachsen und Böhmen" funded by the EU programme INTERREG VA. We thank Christian Tinapp and an anonymous reviewer as well as the guest editor, Hans von Suchodoletz, who made very helpful comments on an earlier version of the manuscript.

\section{References}

Beug, H.-J.: Leitfaden der Pollenbestimmung für Mitteleuropa und angrenzende Gebiete, Pfeil, München, 2004.

Billig, G. and Geupel, V.: Entwicklung, Form und Datierungen der Siedlungen in der Kammregion des Erzgebirges, Siedlungsforschung, Archäologie, Geschichte, Geographie, 10, 173-194, 1992.

Cappers, R. T. J., Bekker, R. M., and Jans, J. E. A.: Digital zadenatlas van Nederland/Digital seed atlas of the Netherlands, Eelde: Barkhuis, 2012.

Ermisch, H.: Dohna und die Dohnaische Fehde, Die Grenzboten, 61, 77-86, 1902.

GK 25: Geologische Karte von Sachsen, 1:25000, Blatt 101 Dippoldiswalde-Glashütte, 1915.

Göhler, M. and Wehmeyer M.: Montanarchäologisch Kartierungen, in: ArchaeoMontan 2012, edited by: Smolnik, R., Erkunden - Erfassen - Erforschen, Arbeits- und Forschungsberichte zur sächsischen Bodendenkmalpflege, Beiheft 26, LfA Sachsen, Dresden, 197-203, 2013.

Hoffmann, Y.: Die Geschichte von Dippoldiswalde bis zum Ende der ersten Bergbauperiode um 1400. Arbeits- und Forschungsberichte zur sächsischen Bodendenkmalpflege, 51/52, 391-421, 2011.

Hrubý, P., Hejhal, P., Malý, K., Kočár, P., and Petr, L.: Centrální Českomoravská vrchovina na prahu vrcholného středověku: archeologie, geochemie a rozbory sedimentárních výplní niv [Central Bohemian-Moravian highlands on the threshold of the high middle ages: archaeology, geochemistry and the analyses of alluvial sediments] Opera Universitatis Masarykianae Brunensis, Facultas Philosophica, 422, Masaryk Univ., Brno, 2014.

Hürkamp, K., Raab, T., and Völkel, J.: Two and three-dimensional quantification of lead contamination in alluvial soils of a historic mining area using field portable X-ray fluorescence (FPXRF) analysis, Geomorphology, 110, 28-36, 2009.

Kenzler, H.: The medieval settlement of the Ore Mountains, The development of the settlement structure, in: Medieval Rural Settlement in Marginal Landscapes, edited by: Klápšte, J. and Sommer, P., Brepolis, Turnhout, 379-392, 2009.

Kenzler, H.: Bergbau und Kolonisation, Die Rolle des Montanwesens innerhalb der mittelalterlichen Besiedlungsgeschichte des Erzgebirges, in: ArchaeoMontan 201, edited by: Smolnik, R., Erkunden - Erfassen - Erforschen, LfA Sachsen, Dresden, 157163, 2013.

Knapp, H., Nelle, O., and Kirleis, W.: Charcoal usage in medieval and modern times in the Harz Mountains Area, Central Germany: Wood selection and fast overexploitation of the woodlands, Quatern. Int., 366, 51-69, 2015.

Mechelk, H.: Zur Frühgeschichte der Stadt Dresden und zur Herausbildung einer spätmittelalterlichen Keramikproduktion im säch- 
sischen Elbgebiet aufgrund archäologischer Befunde, Dt. Verl. Wissenschaft, Berlin, 1981.

Müller, G.: Zwischen Müglitz und Weißeritz. Ergebnisse der heimatkundlichen Bestandsaufnahme im Gebiet Dippoldiswalde/Glashütte, Akademie-Verlag, Berlin, 1964.

Oberdorfer, E.: Pflanzensoziologische Exkursionsflora für Deutschland und angrenzende Gebiete, Ulmer, Stuttgart, 2001.

Reinhold, F.: Die Bestockung der kursächsischen Wälder im 16. Jahrhundert, Baensch, Dresden, 1942.

Reinisch, R.: Erläuterungen zur Geologischen Karte von Sachsen 1:25000. Nr. 101 Blatt Dippoldiswalde-Glashütte, Kauffmanns, Leipzig, 1915.

Schlöffel, M.: Die postglaziale Waldgeschichte der Lehmhaide. Rekonstruktion spät- und postglazialer Umweltbedingungen an einem Torfprofil aus dem Erzgebirge, Arbeits- und Forschungsberichte zur sächsischen Bodendenkmalpflege, 51/52, 9-27, 2010.

Schmidt-Wygasch, C., Schamuhn, S., Meurers-Balke, J., Lehmkuhl, F., and Gerlach, R.: Indirect dating of historical land use through mining: Linking heavy metal analyses of fluvial deposits to archaeobotanical data and written accounts, Geoarchaeology, 25, 837-856, 2010.

Schröder, F.: Die montanarchäologischen Ausgrabungen in Niederpöbel (2011-2013) - Befunde und Ergebnisse, in: ArchaeoMontan 2015, edited by: Smolnik, R., Montanarchäologie im Erzgebirge, LfA Sachsen, Dresden, 23-166, 2015.

Schwabenicky, W.: Beziehungen zwischen Burgen und Bergbau im sächsischen Erzgebirge, Burgenforschung in Sachsen, 9, 9-29, 1996.
Schweingruber, F. H.: Anatomie europäischer Hölzer, Haupt, Bern, 1990.

Shakesby, R. A. and Doerr, S. H.: Wildfire as a hydrological and geomorphological agent, Earth-Sci. Rev., 74, 269-307, 2006.

Stebich, M.: Beiträge zur Vegetationsgeschichte des Georgenfelder Hochmoores, Dissertation Universität Leipzig, Leipzig, 1995.

Stolz, C. and Grunert, J.: Late Pleistocene and Holocene landscape history of the central Palatinate forest (Pfälzerwald, southwestern Germany), Quatern. Int., 222, 129-142, 2010.

Tolksdorf, J. F., Elburg, R., Schröder, F., Knapp, H., Herbig, C., Westphal, T., Schneider, B., Fülling, A., and Hemker, C.: Forest exploitation for charcoal production and timber since the 12th century in an intact medieval mining site in the Niederpöbel Valley (Erzgebirge, Eastern Germany), J. Archaeol. Sci., 4, 487$500,2015$.

Tolksdorf, J. F., Petr, L., Schubert, M., Herbig, C., Kaltofen, A., Matson, S., and Hemker, C.: Palaeoenvironmental reconstruction in the mining town of Freiberg (Lkr. Mittelsachsen) in Saxony, from the 12th century onwards, Archaol. Korresponden., 48, 281-296, 2018.

Wagenbreth, O.: Bergbau im Erzgebirge: technische Denkmale und Geschichte, Dt. Verl. für Grundstoffindustrie, Leipzig, 1990.

Westphal, T., Heußner, K.-U., and Herbig, C.: Holz am Berg - Holz im Bergwerk, in: ArchaeoMontan 2014, edited by: Smolnik, R., Ergebnisse und Perspektiven, LfA Sachsen, Dresden, 243-256, 2014. 